\title{
Current barriers for developing clinical research in Latin America: A cross-sectional survey of medical oncologists
}

\author{
Henry L. Gómez ${ }^{1 *}$, Joseph A. Pinto ${ }^{2}$, Carlos Castañeda ${ }^{1}$ and Carlos S. Vallejos ${ }^{1}$ \\ ${ }^{1}$ Department of Medical Oncology, Oncosalud-AUNA, Peru \\ ${ }^{2}$ Unidad de Investigación Básica y Traslacional, Oncosalud-AUNA, Peru
}

\begin{abstract}
Background: Latin America is a preferred site for sponsors to set clinical trials; however, perceptions by oncologists regarding existing roadblocks for clinical research have not been described. We surveyed Latin American medical oncologists in order to identify the most common barriers to conducting clinical research in their countries.

Methods: We developed a web-based questionnaire-survey with Yes/No, 6-point scale rating, and open-ended questions. Four domains were covered: education, regulatory, financial management and study management. Respondents (identified from the ASCO's membership directory) were requested to list strengths, weakness, opportunities and threats in conducting clinical research.

Results: Ninety three medical oncologists completed the survey, of which 82 were either Principal or co-investigators. The levels of education of researchers and ethical committees were perceived as good. In general, regulatory conditions were considered complex, and Brazilian oncologists considered their regulatory context to be the more complex; despite this, however, they had better financial management of their research groups. Argentinean, Mexican and Peruvian oncologists had a higher proportion of respondents with plans for ensuring development and succession for their research groups. Cost for proposed study approval and procedures were considered high. Although a low density of clinical trials (\#trials/\#sites) is perceived, medical oncologists reported significant interest by local patients and researchers in participating in clinical research. Other barriers were listed in the SWOT.
\end{abstract}

Conclusions: Barriers identified include regulatory, low budgets, high costs, and poor financial management. Perceived strengths were the prevailing education levels in personnel, the interest of patients and researchers in participating in trials and the willingness of researchers to get involved in large academic trials.

\section{Introduction}

Over the last decade, clinical researchers and sponsors have shown an increased interest in conducting medical research in resourcelimited countries, notably Asia, Africa and South America. This movement to fast-growing economies is not limited to only medical research but applies to other areas of research and development (R\&D) [1] despite the low percentage of GDP invested in local R\&D [2].

Each region has similar and particular barriers regarding regulations, ethical concerns, facilities, financial management and others aspects of clinical research. Although the most frequent medical research in the region is industry-sponsored, many conditions differ between high and low income countries. Investigators in the poorest settings have to face similar but greater troubles than those in academic trials in developed countries [3].

Although some works explored barriers to clinical research on specific matters, for example education and psychosocial barriers in developed settings [4,5], there is a lack of knowledge about perceptions of medical oncologists from emerging countries regarding barriers to conduct clinical research locally, despite the great interest of academy and industry from developed countries in off-shoring medical research.

The main barriers to develop clinical research are in domains such as education, regulatory, financial and study management. In emerging regions clinical researchers are typically less experienced in conducting clinical trials than their colleagues in developed countries. However, in some locations, such as Latin America, they have 7 years of experience on average, and conduct two trials per year; many of them speak foreign languages and have high-level training received in the U.S. or Europe [6]. In regard to the regulatory domain, complex conditions could discourage investigators and influence the sponsor's choice toward selecting other countries to open new clinical trials. This is similar in financial aspects, with increased costs, delays associated with payments and the risk of criminal penalties for errors, making research less attractive [7].

We surveyed medical oncologists from Latin American countries in order to familiarize ourselves with their perceptions regarding the commonest barriers to successfully conducting clinical research in their countries and identify strengths, weakness, opportunities and threats in the region.

\section{Methods}

\section{Study design}

This study was part of a learning initiative regarding perceptions

Correspondence to: Henry L Gómez, Department of Medical Oncology, Oncosalud-AUNA, Av. Guardia Civil 571, San Borja, Lima 41, Perú; E-mail: hgomezmoreno@gmail.com

Key words: clinical trials, perception, regulatory, financial management

Received: March 13, 2015; Accepted: April 29, 2015; Published: May 04, 2015 
by researchers from emerging countries in different continents. We delivered a questionnaire to medical oncologists intended to gather their perceptions about barriers to developing clinical research in their respective countries.

\section{Selection of study participants}

We conducted a search in the membership directory of the American Society of Clinical Oncology. The criteria for the search were "medical oncology" and "country name". The email addresses were retrieved and an invitation letter and a link for the survey were sent to 404 medical oncologists from Latin American countries.

\section{Development of the questionnaire}

A self-administrated anonymous web-questionnaire was developed (www.encuestafacil.com). Survey questions were divided into 4 domains and included 3 questions regarding education, 8 about local regulations, 10 on financial management and 13 questions about study management. The survey contained Yes/No questions, open-ended questions, and questions on a 6-point scale rating ( 0 meaning low and 5 meaning high) to have respondents commit to giving either a positive or negative value in the scale without any neutral or ambivalent answer choices.

Respondents were also requested to participate in a SWOT analysis, and list strengths, weakness, opportunities and threats regarding the performance of clinical research in their countries on an equal-priority basis.

\section{Statistical analysis}

Unless otherwise noted, frequency data describing the responses to each question are expressed in terms of the rating median and $25^{\text {th }}$ and $75^{\text {th }}$ percentile. We compared responses among individual countries.

\section{Results}

\section{Characteristics of participants}

Ninety three Latin America oncologists responded to the survey, and 82 were involved in clinical research as principal or co-researchers and were included in the analysis: Argentina (24); Brazil (11), Chile (2); Colombia (9); Dominican Republic (3); Mexico (18), Panama (4), Peru (8); Uruguay (2), and Venezuela (4). For the purpose of this analysis, countries with less than 8 respondents (Chile, Dominican Republic, Uruguay, Panama and Venezuela) were categorized as "other countries".

\section{Educational facts}

Almost all surveyed oncologists have the appreciation that training and capabilities influence the development of the clinical trial When was analysed the perception of education levels of physicians, it was perceived as good in the region (the median rating was 4 ). The lower rating was in Peru and Brazil. In the question about the level of education of the ethical committees, the median rating was 4 and the lower rating was done by Peruvian oncologists (rated as 2) (Table 1).

\section{Regulatory facts}

While in an overall analyses the regulatory context was rated with a median of 3 (out of 5 points) where medical oncologists from Brazil had the worst perception about their regulatory context (median scored as 1); in contrast, Brazilian oncologist had the best perception about procedures for import/export study drugs (5). The worst perception
Table 1. Educational facts.

\begin{tabular}{|c|c|c|c|c|}
\hline & & Rating median & $25^{\text {th }}$ percentile & $75^{\text {th }}$ percentile \\
\hline \multirow{7}{*}{$\begin{array}{l}\text { Education level of local } \\
\text { physicians involved in } \\
\text { Clinical Trials is: }\end{array}$} & Total & 4 & 3 & 5 \\
\hline & Argentina & 4 & 4 & 5 \\
\hline & Brazil & 3 & 3 & 4 \\
\hline & Columbia & 4 & 3 & 5 \\
\hline & Mexico & 4 & 3 & 5 \\
\hline & Peru & 3 & 3 & 3.5 \\
\hline & Other & 4.5 & 4 & 5 \\
\hline \multirow{8}{*}{$\begin{array}{l}\text { Education level of local } \\
\text { ethical committees is: }\end{array}$} & Total & 4 & 3 & 4 \\
\hline & Argentina & 4 & 3 & 4 \\
\hline & Brazil & 4 & 3 & 4 \\
\hline & Columbia & 4 & 3 & 4 \\
\hline & Mexico & 4 & 3 & 4 \\
\hline & Peru & 2 & 1.5 & 3 \\
\hline & Other & 3.5 & 3 & 4 \\
\hline & & Yes & & No \\
\hline \multirow{7}{*}{$\begin{array}{l}\text { Do you consider that } \\
\text { training and capabilities } \\
\text { of the research } \\
\text { team influence the } \\
\text { development and results } \\
\text { of the Clinical Trials? }\end{array}$} & Total & 2 & & 80 \\
\hline & Argentina & 0 & & $24(100 \%)$ \\
\hline & Brazil & 0 & & $11(100 \%)$ \\
\hline & Columbia & 0 & & $9(100 \%)$ \\
\hline & Mexico & $1(5.6 \%)$ & & $17(94.4 \%)$ \\
\hline & Peru & 0 & & $8(100 \%)$ \\
\hline & Other & $1(8.3 \%)$ & & $11(91.7 \%)$ \\
\hline
\end{tabular}

about this issue in the region occurred in Peru and Argentina (median scored as 3). The higher proportion of LATAM medical oncologists (56.2\%) describe a time to study approval of 3-6 months, while a longer time was described in Brazil (72.7\% respond $>9$ months). In overall, $58.3 \%$ of Oncologists says the time to importation of study drug is $<6$ months. In Argentina and Peru are described a shorter time $(<6$ months in $83.3 \%$ and $75 \%$, respectively). In overall, only $22 \%$ percent of surveyed says is difficult to approve only-placebo studies. In all surveyed a $24.4 \%$ respond there is a limited number of studies that a researcher can conduct, while $100 \%$ of Peruvian oncologist agreed it (Table 2).

\section{Financial facts}

In overall, the perception of cost destined to study approval rated as 3 (where 5 was the better score). Mexican oncologist had the worst perception about this fact (median rated as 1). The overall median for cost for study procedures was rated as 4 where only Brazilian oncologists rated this issue with a median of 3 . The proportion that responds that there are differences in costs of approval between academic vs industry trial was in overall $63.4 \%$, where $100 \%$ of Colombian oncologist says the costs are different. On the other hand, the cost for the overhead was different for $75.6 \%$ of surveyed, where in Peru, a half on oncologist respond it is different. Only $36.6 \%$ of surveyed respond they have a positive financial management between 2009 and 2010 (Table 3).

The perception regarding the research funding level stood at 3-points or less; however perception regarding study procedures was that they were highly considered in all countries (the $50^{\text {th }}$ percentile was at 4-points) except for Brazil (at 3-points). Brazil had a higher percentage of oncologists saying that financial management was positive (54.5\%) followed by Peru (37.5\%). The highest percentage of oncologists stating it was not measured occurred in Mexico (38.9\%). Something similar was observed when they were requested to compare their earnings in 2009-2010 with those in 2008-2009, where a major proportion of Brazilian oncologists said it was higher in 2009-2010. The main sponsors were private according more than $40 \%$ of the 
Table 2. Regulatory facts.

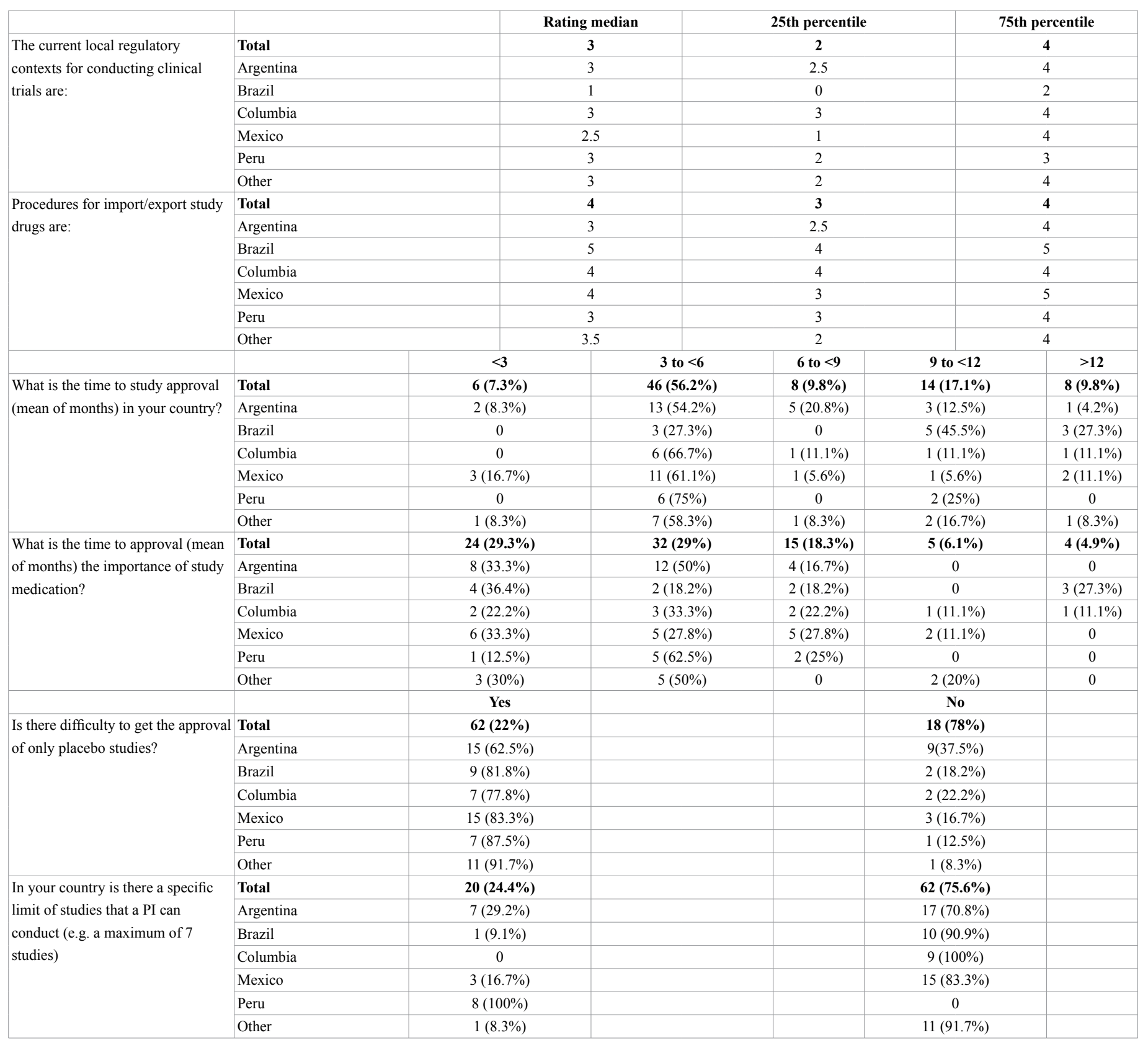

oncologists in all countries (100\% in Brazil, 66.7\% in Argentina, $55.6 \%$ in Columbia, 50\% in Peru and $41.2 \%$ in Mexico). In Colombia, $100 \%$ of oncologists said there are differences in the costs of study approvals between academic and industry trials, while $50 \%$ of Peruvian oncologists said there is no difference. In addition, $50 \%$ of Peruvian oncologists said there are no differences in overhead costs between academic an Industry trials, while $>60 \%$ of the oncologists from other countries said there is a difference.

\section{Study management facts}

The best physician-patient relationship was perceived in Colombia (with the $50^{\text {th }}$ percentile standing at 5-points), followed by Argentina, Brazil, Mexico (4-points) and Peru (3-points). The lowest rates of enrolment were perceived in Colombia (2-points) followed by
Peru (2.5 points) and Argentina, Brazil and Mexico (3-points). The rates of adherence to the study protocol were perceived to be good (4-points) in Argentina, Colombia, Mexico and Peru, while in Brazil, the $50^{\text {th }}$ percentile stood at 3 -points. The interest of local patients in participating in clinical trials was perceived to be best in the case of Brazilian and Peruvian Oncologists (4-points) while the highest interest of local researchers in participating in clinical trials was perceived in Argentina and Mexico (4-points) followed by Brazil, Colombia and Peru (3-points).

In regard to the perception about the density of trials (\#trials/\#sites) compared to other regions, it was considered that lower densities occurred in Brazil and Colombia (1-point), followed by Mexico (2-points) and Argentina and Peru (3-points). Regarding the level of 
Table 3. Financial facts.

\begin{tabular}{|c|c|c|c|c|c|c|c|}
\hline & & & & Rating median & $25^{\text {th }}$ & entile & $75^{\text {th }}$ percentile \\
\hline How do you consider the $\mathrm{c}$ & & Total & & 3 & & & 4 \\
\hline destined for study approva & & Argentina & & 3 & & & 3.5 \\
\hline & & Brazil & & 3 & & & 4 \\
\hline & & Columbia & & 2 & & & 4 \\
\hline & & Mexico & & 1 & & & 3 \\
\hline & & Peru & & 2 & & & 3 \\
\hline & & Other & & 1 & & & 4 \\
\hline You consider that costs for & & Total & & 4 & & & 5 \\
\hline study procedures are: & & Argentina & & 4 & & & 4.5 \\
\hline & & Brazil & & 3 & & & 4.5 \\
\hline & & Columbia & & 4 & & & 5 \\
\hline & & Mexico & & 4 & & & 5 \\
\hline & & Peru & & 4 & & & 4 \\
\hline & & Other & & 3.5 & & & 5 \\
\hline & & & & & & & No \\
\hline Is there a difference for the & & Total & & & & & $0(36.6 \%)$ \\
\hline cost of approval between & & Argentina & & & & & $1(45.8 \%)$ \\
\hline academic trials VS industr & & Brazil & & & & & $4(36.4 \%)$ \\
\hline trials & & Columbia & & & & & 0 \\
\hline & & Mexico & & & & & $4(22.2 \%)$ \\
\hline & & Peru & & & & & $4(50 \%)$ \\
\hline & & Other & & & & & $7(58.3 \%)$ \\
\hline In your site, is there a & & Total & & & & & $0(24.4 \%)$ \\
\hline difference between the cos & & Argentina & & & & & $6(25 \%)$ \\
\hline for overhead in academic & & Brazil & & & & & $2(18.2 \%)$ \\
\hline trials vs. industry trials? & & Columbia & & & & & $1(11.1 \%)$ \\
\hline & & Mexico & & & & & $3(16.7 \%)$ \\
\hline & & Peru & & & & & $4(50 \%)$ \\
\hline & & Other & & & & & $4(3.3 \%)$ \\
\hline & & & Positive & Negative & In Zero (0) & It was not measured & Confedential information \\
\hline In regard to the financial & Tota & & $30(36.6 \%)$ & $12(14.6 \%)$ & $18(22 \%)$ & $16(19.5 \%)$ & $6(7.3 \%)$ \\
\hline management of your & Arge & gentina & $8(33.3 \%)$ & $4(16.7 \%)$ & $6(25 \%)$ & $3(12.5 \%)$ & $3(12.5 \%)$ \\
\hline research group, in the & Braz & & $6(54.5 \%)$ & $1(9.1 \%)$ & $2(18.2 \%)$ & $1(9.1 \%)$ & $1(91.1 \%)$ \\
\hline & Colu & umbia & $3(33.3 \%)$ & $2(22.2 \%)$ & $2(22.2 \%)$ & $2(22.2 \%)$ & 0 \\
\hline & Mex & xico & $6(33.3 \%)$ & $3(16.7 \%)$ & $2(11.1 \%)$ & $2(11.1 \%)$ & $1(5.6 \%)$ \\
\hline & Peru & & $3(37.5 \%)$ & $1(12.5 \%)$ & $3(37.5 \%)$ & $3(37.5 \%)$ & 0 \\
\hline & Othe & & $4(33.3 \%)$ & $1(8.3 \%)$ & $3(25 \%)$ & $3(25 \%)$ & $1(8.3 \%)$ \\
\hline & & & Higher & Lower & Equal & It was not measured & Confedential information \\
\hline In regard to the financial & Tota & & $10(12.3 \%)$ & $24(29.6 \%)$ & $22(27.2 \%)$ & $19(23.5 \%)$ & $6(7.4 \%)$ \\
\hline management of your & Arge & sentina & $2(8.3 \%)$ & $8(33.3 \%)$ & $7(29.2 \%)$ & $4(16.7 \%)$ & $3(12.5 \%)$ \\
\hline $\begin{array}{l}\text { research group, in } \\
\text { comparision of the }\end{array}$ & Braz & & $5(45.5 \%)$ & $4(36.4 \%)$ & 0 & $1(9.1 \%)$ & $1(9.1 \%)$ \\
\hline earned in $2008-2009$, in & Colu & umbia & $1(11.1 \%)$ & $3(33.3 \%)$ & $3(33.3 \%)$ & $2(22.2 \%)$ & 0 \\
\hline 2009-2010, it was: & Mex & xico & $1(5.6 \%)$ & $4(22.2 \%)$ & $5(27.8 \%)$ & $7(38.9 \%)$ & $1(5.6 \%)$ \\
\hline & Peru & & 0 & $3(37.5 \%)$ & $4(50 \%)$ & $1(12.5 \%)$ & 0 \\
\hline & Othe & & $1(9.1 \%)$ & $2(18.2 \%)$ & $3(27.3 \%)$ & $4(36.4 \%)$ & $1(9.1 \%)$ \\
\hline & & & Private & Mixed & Own resources & Different internation & al institutions \\
\hline The main sponsers of & Tota & & $47(57.3 \%)$ & $20(20.4 \%)$ & $5(6.1 \%)$ & $8(9.8 \%)$ & \\
\hline the proposal approved & Arge & gentina & $16(66.7 \%)$ & $5(20.8 \%)$ & 0 & $3(12.5 \%)$ & \\
\hline in 2009-2010 of your & Braz & & $11(100 \%)$ & 0 & 0 & 0 & \\
\hline & Colu & umbia & $5(55.6 \%)$ & $2(22.2 \%)$ & $2(22.2 \%)$ & 0 & \\
\hline & Mex & xico & $7(41.2 \%)$ & $7(41.2 \%)$ & $7(41.2 \%)$ & $2(11.8 \%)$ & \\
\hline & Peru & & $4(50 \%)$ & $2(25 \%)$ & $2(25 \%)$ & $1(12.5 \%)$ & \\
\hline & Othe & & $4(36.4 \%)$ & $4(36.4 \%)$ & $4(36.4 \%)$ & $2(16.7 \%)$ & \\
\hline
\end{tabular}

competition in Latin America and other emerging regions (Eastern Europe, Asia and the Middle East), the highest levels were perceived for Argentinean Oncologists (4-points) followed by Mexico (3.5-points) and Brazil, Colombia and Peru (3-points). With regard to plans for development and succession that guarantee the continuity of their research group, the percentage of those who approved was $79.2 \%$ in 
Table 4. Study management facts.

\begin{tabular}{|c|c|c|c|c|}
\hline & & $\begin{array}{l}\text { Rating } \\
\text { median }\end{array}$ & $\begin{array}{c}25^{\text {th }} \\
\text { percentile }\end{array}$ & $\begin{array}{c}75^{\text {th }} \\
\text { percentile }\end{array}$ \\
\hline \multirow{7}{*}{$\begin{array}{l}\text { How do you consider } \\
\text { the physician-patients } \\
\text { relationship in your country? }\end{array}$} & Total & 4 & 4 & 4 \\
\hline & Argentina & 4 & 4 & 4 \\
\hline & Brazil & 4 & 3 & 4 \\
\hline & Columbia & 5 & 4 & 5 \\
\hline & Mexico & 4 & 4 & 4 \\
\hline & Peru & 4 & 3 & 4 \\
\hline & Other & 4 & 4 & 5 \\
\hline \multirow{7}{*}{$\begin{array}{l}\text { How were the enrollment } \\
\text { rates on last year (2010)? }\end{array}$} & Total & 3 & 2 & 4 \\
\hline & Argentina & 3 & 2.5 & 4 \\
\hline & Brazil & 3 & 2.5 & 4 \\
\hline & Columbia & 2 & 1 & 3 \\
\hline & Mexico & 3 & 1 & 4 \\
\hline & Peru & 2.5 & 1 & 3.5 \\
\hline & Other & 3.5 & 2 & 4 \\
\hline \multirow{7}{*}{$\begin{array}{l}\text { How were the rates of } \\
\text { adherence to protocol study? }\end{array}$} & Total & 4 & 3 & 5 \\
\hline & Argentina & 4 & 3 & 4.5 \\
\hline & Brazil & 4 & 2.5 & 5 \\
\hline & Columbia & 4 & 3 & 4 \\
\hline & Mexico & 4 & 3 & 5 \\
\hline & Peru & 4 & 3.5 & 4 \\
\hline & Other & 4 & 4 & 4.5 \\
\hline \multirow{7}{*}{$\begin{array}{l}\text { Interest of local patients } \\
\text { to participate in clinical } \\
\text { trials is: }\end{array}$} & Total & 3 & 2 & 4 \\
\hline & Argentina & 2 & 3 & 3 \\
\hline & Brazil & 4 & 2 & 4.5 \\
\hline & Columbia & 3 & 2 & 3 \\
\hline & Mexico & 3 & 3 & 4 \\
\hline & Peru & 2 & 3 & 3.5 \\
\hline & Other & 4 & 4 & 4 \\
\hline \multirow{7}{*}{$\begin{array}{l}\text { Interest of local investigators } \\
\text { to participate in clinical } \\
\text { trials is: }\end{array}$} & Total & 4 & 3 & 4 \\
\hline & Argentina & 4 & 3 & 4.5 \\
\hline & Brazil & 4 & 2 & 5 \\
\hline & Columbia & 3 & 3 & 4 \\
\hline & Mexico & 4 & 3 & 4 \\
\hline & Peru & 3 & 2 & 4.5 \\
\hline & Other & 4 & 2 & 4.5 \\
\hline \multirow{7}{*}{$\begin{array}{l}\text { How do you consider the } \\
\text { density of clinical trials (\#of } \\
\text { trials / \# of sites) in your } \\
\text { country compared other } \\
\text { regions? }\end{array}$} & Total & 2 & 1 & 3 \\
\hline & Argentina & 3 & 2 & 3 \\
\hline & Brazil & 1 & 1 & 2 \\
\hline & Columbia & 1 & 1 & 2 \\
\hline & Mexico & 2 & 2 & 3 \\
\hline & Peru & 2 & 3 & 4 \\
\hline & Other & 1 & 0 & 3 \\
\hline \multirow{8}{*}{$\begin{array}{l}\text { In regard to clinical } \\
\text { research, what is the level } \\
\text { of competition of the region } \\
\text { (Latin America) with } \\
\text { other emerging countries } \\
\text { of Eastern Europe, Asia, } \\
\text { Middle East? }\end{array}$} & Total & & & \\
\hline & Argentina & 4 & 2.5 & 5 \\
\hline & Brazil & 3 & 2 & 4 \\
\hline & Columbia & 3 & 3 & 4 \\
\hline & Mexico & 3.5 & 2 & 4 \\
\hline & Peru & 3 & 3 & 4 \\
\hline & Other & 3 & 1.5 & 4 \\
\hline & & \multicolumn{2}{|c|}{ Yes } & No \\
\hline \multirow{7}{*}{$\begin{array}{l}\text { There are plans of } \\
\text { development and succession } \\
\text { that guarantee the continuity } \\
\text { of your research group? }\end{array}$} & Total & \multicolumn{2}{|c|}{$56(68.3 \%)$} & $26(37.1 \%)$ \\
\hline & Argentina & \multicolumn{2}{|c|}{$19(79.2 \%)$} & $5(20.8 \%)$ \\
\hline & Brazil & \multicolumn{2}{|c|}{$4(36.4 \%)$} & $7(63.6 \%)$ \\
\hline & Columbia & \multicolumn{2}{|c|}{$5(55.6 \%)$} & $4(44.4 \%)$ \\
\hline & Mexico & \multicolumn{2}{|c|}{$14(77.8 \%)$} & $4(22.2 \%)$ \\
\hline & Peru & \multicolumn{2}{|c|}{$6(75.0 \%)$} & $2(25.0 \%)$ \\
\hline & Other & \multicolumn{2}{|c|}{$8(66.7 \%)$} & $4(33.3 \%)$ \\
\hline
\end{tabular}

Argentina, $77.8 \%$ in Mexico, $75.0 \%$ in Peru, $55.6 \%$ in Colombia and $36.4 \%$ in Brazil.

\section{Swot analysis}

In supplementary table 1 , the strengths, weakness, opportunities and threats perceived by the medical oncologists in regard to local clinical research are listed. Although most researchers did not complete this section, information was retrieved from 12 oncologists from Argentina, 11 from Mexico, 8 from Brazil, 6 from Colombia, 6 from Peru and 6 from other countries.

Latin American oncologists perceived that the strengths were the low costs, the absence of competing studies, the interest of physicians, the education of team members, the strong enrolment rates, young people participating in trials, and the quality of data. The perceived weaknesses were the amateurish financial management, the high costs, the absence funding for public centres, the regulations, the poor training of research teams, the lack of research regarding local needs, the insufficient staff, the lack of understanding of the potential benefits of clinical research by local Institutions, and researchers not being considered equal to US investigators (Latin American personnel is considered cheaper). Opportunities were the low level of competition, cooperative work, and government support, research with biosimilars, the high incidence of cancer, significant industry interest, and the growing lung, prostate, and gastric cancer populations. The threats were the lack of interest, the overwhelming regulatory burden, and the unnecessary regulatory requirements locally and in other developed countries, taxes, regulatory delays, the decreasing budget for researchers and lower funding from industry.

We were able to see diverse responses, and several times we observed that while some oncologists think that there are well trained professionals for conducting clinical research, others believe that there are educational deficiencies. Regarding threats, it is remarkable that the perception in some regions is that there is a lack of interest of researchers in several regions although some surveyed responded that they have good levels of education (Supplementary Table S1).

\section{Discussion}

Our aim is not to discuss the ethical concerns in developing clinical research in Latin America - a subject that always is a matter of controversy-, but to describe the perceptions of medical oncologists about barriers in their countries.

The migration of the pharmaceutical Industry and academic research to emerging countries is well-known. In that sense, variables that promote or make difficult clinical research must be identified and clearly described. Migration of clinical trials is partially explained by some general features of those countries, such as their heterogeneous and growing populations, high prevalence of targeted diseases and lower research costs - even for similar labour force quality and research conditions relative to developed countries [8]. Although advantageous conditions include cheaper treatment (costs are 30\% of those in the United States), reduced and cheaper domestic travel and lower costs of support services [9], the perception of Latin American Oncologists was one of high costs for study approvals and procedures for trials and low budgets.

Initiatives such as the organization of research groups, such as GECOPERU, GOCHI, GAICO, LACOG, and others, improve the opportunity to establish regional alliances. Local research is important, not only for patients but to researchers and other individuals that 
have clinical research incomes; in addition, true capacity-building is best achieved by establishing a community of developing-country based researchers to share locally derived solutions and build a set of validated methods and operational tools that will enable pragmatic and locally-led development [2].

Undoubtedly, the education of research team plays a central role in the success of the clinical trials. In Argentina Colombia and Mexico, oncologists had a better perception than oncologists from Brazil and Peru about the level of education of local physicians involved in clinical research, while in Peru, oncologists had the worst perception about the educational level of ethics committees. Although there are programs developed under the sponsorship of Peru's National Institute of Health through collaborations between the U.S. Naval Medical Research Centre Detachment, the University of Washington and the Department of Clinical Bioethics of the National Institutes of Health, to provide training in the ethical conduct of research to IRB members and researchers from Peru, reports on the findings of inspections by the regulatory authority determined that these interventions had no impact on the protection of research subjects [10,11]. A guideline and guide for reviewing the ethical and scientific aspects of clinical trials was developed [12]. A poor educational level is a barrier given that studies could be approved, but these could be observed by the regulatory authority, increasing the times to effective study approvals.

The regulatory environment is also another aspect that is perceived to make the performance of clinical research in these scenarios difficult. There are more oncologists identifying regulation as a problem than oncologists that think the regulatory environment is favourable. Brazilian Oncologists have the worst perception about their regulatory context; this was also observed in the time to study approval or times for study drug importation. A report by Metzger-Filho about timelines to set up the ALTTO Trial show that the South America region had the longest time to regulatory authority approval (median 236 days); however there was a wide range (21-257 days). There were significant differences with Europe but not North America or Asia Pacific, although this had no influence on the recruitment period [13].

Studies conducted in Latin America have shown that simple wellorganized trials pay off well above expectations, even with minimum funding but maximum zeal and determination. ${ }^{4}$ This situation has brought about two points of view: from the Investors standpoint, these countries provide a cheaper way to obtain good quality results, and as far as the local Investigators are concerned, many of them see their work as undervalued. Although, the importance of clinical trials by cooperative groups is well known, a very significant issue is that researchers from emerging countries have limited participation in these kinds of studies.

Financial management of research groups is a relevant issue. Lang et al. propose that to improve clinical trials conducted in resourcelimited settings not only is skilled staff needed, but also easier operational tools and guidance. ${ }^{2}$ This could be achieved by organizing local or regional research groups with centralized facilities and centralized administrative and financial management. Preparedness and adaptability are essential ingredients for successful conduct of clinical trials in any setting, especially resource poor settings. Having an administrative officer dedicated to handling administrative issues related to the trial can be an invaluable asset. This would also allow the scientist to devote more time to the scientific aspects of the trial. This requirement is necessary when the administrative requirements may represent a substantial hindrance to the progress of the trial [14].
Researchers from Latin America are aware that they have a great pool of patients and patient populations with special conditions and they have great interest in participating in clinical research; however they also are aware that they need more training. Financial management is a critical aspect for the development of a clinical trial; however, a great proportion of research groups lack financial statements. Thus, it is difficult to design strategies for the continuity of research groups. In other medical science disciplines, there are opinions that societies are not scientifically conducted and that the allocation of human and economic resources to research is meagre [15].

Clinical Research in developing countries is a good way to get high returns. Medical oncologists are concerned about their strengths and weaknesses and this is very important because it implies a great potential for continued growth. Greater support by industry and cooperative groups is necessary. The main requirements to unlock the clinical trial opportunities in emerging countries include: knowledge of the local regulatory processes and operations, establishing close relationships with local physicians and medical centres, and increased expertise in global regulatory standards and local applications of global processes and systems.

Barriers are not only in terms of infrastructure, but the attitudinal barriers in patients play a fundamental role. Lower educational levels and the female gender, but not race, are independently associated with barriers to clinical trials in regard to fears and emotions [4]. Although in this paper, we are focused on the perception of oncologists about barriers in conducting clinical research, it would be also important to know the attitudinal variables that could influence the trials accrual in Latin America.

Access to academic research groups is difficult due to the limited budgets and all the difficulties involved in opening new sites for clinical research. Unfortunately there is no data about these concerns. It is important to low and middle income countries to carry out local research, given the important role it plays in changing the professional practice of health care providers. In a survey by Guindon et al. it was shown that health care providers use scientific journals from our own country as sources of evidence to change our professional practice; on the other hand, academically-funded research improves the chances of findings being translated into national policy and practice $[16,17]$.

Access to large cooperative groups is a major concern and in this survey, it was identified as a weakness. On a par with organization for financial management, education is a critical point and formal training programs in clinical research and ethics should be developed for researchers in developing countries to expand their global clinical research leadership capacity and improve collaboration between academic researchers worldwide [16,17].

In conclusion, the weak financial management of research groups and inadequate regulatory context are barriers found in Latin America; however, medical oncologists perceive the real potential of the region. The development of strategies for sustainable research groups and access to international academic groups could improve the outlook of the region to conduct clinical research successfully.

\section{Acknowledgments}

We thank Patricia Pairazaman for her technical assistance. We are very grateful to the Medical Oncologists that dedicated part of their valuable time to take the survey. 


\section{Disclosure}

Part of this work was presented as an oral presentation at the ASCO meeting 2010.

\section{References}

1. EIU (2004) Scattering the seeds of invention: The globalisation of research and development. Economist Intelligence Unit, London.

2. Albornoz M, Matos M, Alfaraz C (2010) Latin America. In: UNESCO science report. UNESCO: 77-121.

3. Govindarajan R, Young JW, Harless CL, Hutchins LF (2007) Barriers to clinical trials vary according to the type of trial and the institution. J Clin Oncol 25: 1633-1634. [Crossref]

4. Eads JR, Albrecht, Egleston B, Buzaglo JS, Cohen RB, et al. (2011) Identification of barriers to clinical trials: The impact of education level. J Clin Oncol 29: suppl; abstr 6003 .

5. Meropol NJ, Buzaglo JS, Millard J, Damjanov N, Miller SM, et al. (2007) Barriers to clinical trial participation as perceived by oncologists and patients. J Natl Compr Canc Netw 5: 655-664. [Crossref]

6. Zieher S (2010) Navigating Latin America's Diverse Clinical and Regulatory Landscapes. Foresight 3.

7. Glickman SW, McHutchison JG, Peterson ED, Cairns CB, Harrington RA, et al. (2009) Ethical and scientific implications of the globalization of clinical research. $N$ Engl $J$ Med 360: 816-823. [Crossref]

8. Santiago-Rodríguez F (2009) Facing the trial of internationalizing clinical research to developing countries: evidence from Mexico. In: Editors. Multinationals and emerging economies. The quest for innovation and sustainability. Dolfsma W, Duysters G, Costa I. Edward Elgar Publishing Limited. UK.

9. Varawalla N (2006) C5's forum on ensuring compliance and managing legal risks in structuring and conducting Clinical Trials, London. Clinical trials in emerging markets.

10. Lescano AR, Blazes DL, Montano SM, Moran Z, Naquira C, et al. (2008) Research ethics training in Peru: a case study. PLoS One 3: e3274. [Crossref]

11. Minaya G, Fuentes D, Barboza M (2011) Proceso de Fortalecimiento de Comités de Ética en Investigación en el Perú (Research Ethics Process Strengthening Committees in Peru.) Revista Red bioética/UNESCO 1: 46-54.

12. Hubé F, Mutawe M, Leygue E, Myal Y (2004) Human small breast epithelial mucin the promise of a new breast tumor biomarker. DNA Cell Biol 23: 842-849. [Crossref]

13. Metzger-Filho O, de Azambuja E, Bradbury I, Saini KS, Bines J, et al. (2013) Analysis of regional timelines to set up a global phase III clinical trial in breast cancer: the adjuvant lapatinib and/or trastuzumab treatment optimization experience. Oncologist 18: 134-140. [Crossref]

14. Lang TA, White NJ, Tran HT, Farrar JJ, Day NP, et al. (2010) Clinical research in resource-limited settings: enhancing research capacity and working together to make trials less complicated. PLoS Negl Trop Dis 4: e619. [Crossref]

15. Zegers-Hochschild F (2011) Barriers to conducting clinical research in reproductive medicine: Latin America. Fertil Steril 96: 802-804. [Crossref]

16. Guindon GE, Lavis JN, Becerra-Posada F, Malek-Afzali H, Shi G, et al. (2010) Bridging the gaps between research, policy and practice in low- and middle-income countries: a survey of health care providers. CMAJ 182: E362-E372. [Crossref]

17. Costello A, Zumla A (2000) Moving to research partnerships in developing countries. BMJ 321: 827-829. [Crossref]

Copyright: (C2015 Gómez HL. This is an open-access article distributed under the terms of the Creative Commons Attribution License, which permits unrestricted use, distribution, and reproduction in any medium, provided the original author and source are credited. 